\title{
Research on the Influence of Green Credit in the Operation and Management of Commercial Banks
}

\author{
Hongmin Zhang*, Cong Qin
}

\author{
School of Finance, Harbin University of Commerce, Harbin, China \\ *Corresponding author. Email: zhanghm0315@163.com
}

\begin{abstract}
With the sustainable development of economy, green credit business is gradually developing. As the main body of green credit business, banks must strictly examine and approve the flow of loans to make the credit funds flow to environmental protection enterprises. And this will affect the bank's own operating performance. In order to effectively carry out this business, this article summarizes the status quo of domestic and foreign green credit development and related literature, and establishes a model with relevant green credit data of China's commercial banks from 2013 to 2019, and conducts an empirical analysis. Finally, combined with the existing problems, it provides reference for Chinese commercial banks to better implement green credit business.
\end{abstract}

Keywords: Green credit, Business performance of commercial banks, Sustainable development.

\section{INTRODUCTION}

Since the reform and opening up, China's overall economic production has caused more and more damage to the excessive energy consumption and ecological environment, and the resulting environmental problems have gradually become prominent.In addition to relying solely on administrative means to manage environmental problems, financial means can also be used to control the flow of funds to promote green development of the economy. The green credit system will gradually become the primary core task of China's green economy development. For one thing, China's green finance system is constantly improving and expanding, and the connotation of green finance is constantly innovating and developing. The vast majority of commercial banks actively responded to the government's launch of green credit business, and gradually strengthened their support for energy conservation, environmental protection, and low-carbon fields. For another, the development of green finance is not yet balanced and is still at a preliminary stage. There are also many obstacles hindering the development of green finance, such as incomplete disclosure of relevant environmental protection information and defective communication mechanisms.

Commercial banks directly determine whether the green credit business can be effectively implemented, but the profitability of commercial banks themselves is the main task of their operations. If the green credit business can bring considerable potential benefits to the bank itself, then commercial banks will be more proactive in developing this business. Therefore, this article first analyzes the theoretical basis of commercial banks' operating performance and the status quo of the implementation of green credit, and further empirically analyzes the impact mechanism between the two, and finally provides relevant policy recommendations for the development and improvement of commercial banks' green credit business.

\section{LITERATURE SUMMARY}

The connotation of sustainable finance and environmental finance in foreign related research is equivalent to green credit. Scholtens, Bert and, dam (2006) divided banks into two categories according to whether or not to implement the equator principle, and analyzed their costs and profits respectively. The results show that banks that implement the equator principle have higher fixed costs for a period of time due to the reduction of loan issuance, but they have a good reputation in the society because of their strong awareness of environmental protection, Compared with another kind of bank, the risk level is lower[1].E. J.ciliers et al. (2012) believe that green credit can not only promote environmental protection, but also affect the economic benefits of banks. And through the research, it is shown that there is a positive relationship 
between the two [2]. Eshet (2017) pointed out in his article that the development of green credit business can not only enhance the ability of commercial banks to prevent loan risks. It also contributes to the improvement of social status, and can improve the market competitiveness of the same industry, thereby increasing the profits of commercial banks. [3].

China's research on green credit only started in 2007. Compared with developed countries, all aspects are relatively backward, but after more than ten years of development, rich research results have been achieved. Zhu Guangyin et al. (2017) used empirical analysis to analyze whether there is an inherent motivation for green credit to be implemented. The results show that the implementation of this business by commercial banks has a positive effect on the financial performance of the bank [4]. Through research, Yang Dandan et al. (2019) found that in the long run, the positive impact of green credit on the operating efficiency of banks is significant. This impact will gradually increase in a short period of time and stabilize over time. This shows that the implementation of the bank's green credit has improved its own operational efficiency while fulfilling its social responsibilities [5].

\section{RELEVANT THEORETICAL BASIS}

\subsection{Related Concepts}

\subsubsection{Green Credit}

Green credit means that the bank implements relevant decisions issued by the government in accordance with the requirements of relevant government departments, provides low-interest loan support to companies engaged in low-carbon operations, or uses other methods to encourage loans; and for environmentally destructive enterprises, it adopts improved measures Its credit conditions are subject to penalties for high loan interest rates. What commercial banks need to pay more attention to is to balance the relationship between business performance and sustainable development, and promote the coordinated development and common growth of the two.

\subsubsection{Business Performance of Commercial Banks}

It refers to the commercial banks in the process of operation in the market economy conditions, on the basis of ensuring liquidity and security, through providing financial products and services to customers, from which corresponding profits can be obtained. The performance of commercial banks is not only the embodiment of their profit value, but also the stability of their profit.

\subsection{The Influence Mechanism of Green Credit on Commercial Banks' Performance}

\subsubsection{Green Credit Policy Implementation Can Form a Green Reputation}

The particularity of the asset-liability structure of commercial banks leads to high risks in their business activities. However, commercial banks focus on financial and compliance risks, while ignoring environmental risks. When banks are approving loans, they may issue loans to environmentally polluting enterprises and projects, which will increase the bank's non-performing loans and reduce the bank's operating performance. Therefore, if banks can develop green credit business, strengthen their awareness of social responsibility, and incorporate environmental indicators into the loan approval process, funds will gradually flow to environmentally friendly enterprises, improve the quality of assets, and can establish a good image among the public, and finally form Green reputation. In this way, banks also promoted a balance between maximizing their own profits and environmental protection.

\subsubsection{The Implementation of Green Credit Policy Can Optimize the Credit Structure}

Credit structure refers to the release of credit funds and the ratio of credit funds used in different fields, industries and periods. It is related to the financial security and operating performance of commercial banks. In the current process of issuing credit, commercial banks first regard the environmental risk assessment of the enterprise as the review standard. Commercial banks can give priority to loans to environmental protection enterprises. For enterprises that damage the environment, we should strictly examine and approve their loans, increase their loan interest rates, and even refuse to provide loans. In this way, it can reduce the non-performing loan ratio, optimize the credit structure, promote the sustainable and healthy development of banks, and then improve the operating performance.

\section{EMPIRICAL RESEARCH}

\subsection{Variable Construction and Data Selection}

\subsubsection{Explained Variable}

The average total asset adequacy ratio (ROA) is used as the explained variable. Because the research object is a listed commercial bank, its equity assets account for a small proportion of total assets. Therefore, the average total asset adequacy ratio can better represent the operating performance of commercial banks. 


\subsubsection{Explanatory Variable}

The explanatory variable of this article Green Credit Ratio (GCR). The green credit ratio is selected to represent the implementation of bank credit. The green credit ratio is the percentage of the total loans of commercial banks.

\subsubsection{Control Variables}

This paper uses the core tier one capital adequacy ratio (CTOC) to reflect the capital adequacy of banks; the deposit-loan ratio (LTDR) represents the short-term solvency of commercial banks, that is, the liquidity status; non-performing loan ratio (NPLR); take the logarithm of the bank's total assets to express the bank size (LNGA).

\subsubsection{Data Selection}

Since the object of this article is commercial banks, and Industrial Bank's disclosure standards on green credit are quite different from other banks, it is not used as one of the samples. Finally, 15 listed banks including Industrial and Commercial Bank of China, China Construction Bank and Bank of China were selected for research.

The data used in this empirical analysis is selected from the green credit-related data released by the 15 listed commercial banks from 2013 to 2019. The data comes from the annual reports and social responsibility reports disclosed by banks every year.

\subsection{Correlation Analysis of Variables}

Only when there is a correlation between the research variables can the correct regression results be obtained; otherwise, it may cause spurious regression of variables. Therefore, before establishing the relevant panel model, the correlation analysis between variables should be carried out.

Table 1. Correlation analysis results

\begin{tabular}{|c|c|c|c|c|c|c|}
\hline & ROA & GCR & LNGA & CTOC & NPLR & LTDR \\
\hline ROA & 1 & & & & & \\
\hline GCR & 0.254669 & 1 & & & & \\
\hline LNGA & 0.20287 & 0.554101 & 1 & & & \\
\hline CTOC & 0.4095 & 0.583268 & 0.68734 & 1 & & \\
\hline NPLR & -0.43322 & 0.15857 & 0.497229 & 0.184644 & 1 & \\
\hline LTDR & -0.44146 & -0.10585 & 0.204776 & -0.01202 & 0.594141 & 1 \\
\hline
\end{tabular}

It is not difficult to see that the variables selected in this article are highly correlated. The results of variables correlation analysis show that ROA has a positive relationship with GCR, CTOC and LNGA, and a negative relationship with LTDR and NPLR.

\subsection{Model Establishment}

Because the research object of this article is China's 15 listed commercial banks, green credit data from 2013 to 2019. The panel model is established as follows:

$$
\begin{aligned}
R O A_{i t} & =\alpha_{i}+\beta_{1} G C R_{i t}+\beta_{2} C T O C_{i t}+\beta_{3} L T D R_{i t} \\
& +\beta_{4} N P L R_{i t}+\beta_{5} L N G A_{i t}+\varepsilon_{i t}
\end{aligned}
$$

Among them, banks are distinguished by the subscript $i$; $t$ represents the number of years, $\alpha$ is the intercept term, $\beta$ is the variable coefficient, and $\varepsilon_{\mathrm{it}}$ is the residual; ROA indicates the average return on total assets of the i-th bank in year t; GCR means the i-th bank Bank's green credit ratio in year $t$, and so on.

\subsection{Panel Model Selection}

\subsubsection{F-test}

The F-test assumes that the individuals in the model have the same intercept. The panel data are estimated by mixed regression and fixed effect regression model respectively, and the sum of squares of residuals is $\mathrm{S}_{1}=0.000169, \mathrm{~S}_{3}=3.87 \mathrm{E}-05$..In this article, $\mathrm{N}$ represents the number of listed commercial banks, $\mathrm{T}$ is the time interval, and $\mathrm{K}$ is the number of variable sums.

$\mathrm{F}=\frac{\left(\mathrm{S}_{3}-\mathrm{S}_{1}\right) /(\mathrm{N}-1)}{\mathrm{S}_{1} /(\mathrm{NT}-\mathrm{N}-\mathrm{K})}$

According to the calculation, the statistical value of $F$ is 20.44205 , which is greater than $F_{0.05}(14,85)$ was 1.810. If the original hypothesis does not hold, a fixed effect regression model should be established.

\subsubsection{Hausman test}

The F-test confirms that the model has individual effects, and it is also necessary to consider whether the individual effects of the model are related to explanatory variables. Then proceed to the Hausman test.

Table 2. Huasman Test

\begin{tabular}{|c|c|c|c|}
\hline Test Summary & Chi-Sq. Statistic & Chi-Sq. d.f. & Prob \\
\hline $\begin{array}{c}\text { Cross-section } \\
\text { random }\end{array}$ & 77.299356 & 5 & 0.0000 \\
\hline
\end{tabular}

It can be seen from the test results in Table 2 that the $P$ value is 0 , which is less than 0.01 . This shows that the original hypothesis should be rejected and the fixed effects model is more reasonable.

\subsection{Model Empirical Results and Analysis}

Table 3 shows the regression results of the model: R-squared was 0.883884, adjusted R-squared was 0.857928 . The fitting effect of the established model is better. Because the main body of this paper is green credit and business performance of commercial banks. Therefore, according to the regression results, only the correlation between the two was analyzed. The 
regression coefficient of the explanatory variable GCR is -0.034061 , which means that every unit of GCR increases, commercial banks will reduce their profits by 0.034061 .

Table 3. Panel model regression results

\begin{tabular}{|l|l|l|l|l|}
\hline Variable & Coefficient & Std.Error & t-Statistic & Prob. \\
\hline C & 0.048612 & 0.006073 & 8.004991 & 0.0000 \\
\hline GCR & -0.034061 & 0.009015 & -3.778318 & 0.0003 \\
\hline CTOC & 0.000915 & 0.010651 & 0.085897 & 0.9318 \\
\hline LTDR & 0.001474 & 0.001185 & -1.244094 & 0.2169 \\
\hline NPLR & -0.173442 & 0.031408 & -5.522173 & 0.0000 \\
\hline LNGA & -0.002171 & 0.000434 & -4.995950 & 0.0000 \\
\hline R-squared & 0.883884 & F-statistic & 34.05387 \\
\hline Adjusted R-squared & 0.857928 & Prob(F-statistic) & 0.000000 \\
\hline
\end{tabular}

The empirical results obtained are different from the previous expectations, the following reasons are analyzed: First, in the short term, the green credit of commercial banks will reduce their income. Second, because China's research on green credit is relatively slow, and the implementation of different banks is not the same, the selected data may not be representative. Third, China lacks a platform for sharing environmental information. There is information asymmetry between banks and loan companies.

\section{CONCLUSION}

This article first analyzes the situation related to green credit in China from a theoretical level. Therefore, it is believed that the bank's development of this business can improve its own asset structure and improve the bank's social reputation .Generally speaking, the implementation of green credit has a positive role in promoting bank performance. However, it is contrary to the previous empirical model.

Through further analysis, since China's green credit was launched, although certain development has been achieved, there are still certain obstacles. For example, there is no restriction of relevant legal systems, lack of an environmental evaluation system, commercial banks are still not sufficiently motivated to develop green credit business, etc., and they have not really accepted and internalized green credit.

\section{REFERENCES}

[1] L. Dam. Banking on the Equator. Are Banks that Adopted the Equator Principles Different from Non-Adopters?[J]. World Development, 2006, pp.1307-1328.

DOI:https://doi.org/10.1016/j.worlddev.2006.10.01 3

[2] E.J. Cilliers etal.Sustainable green urban planning: the Green Credit Tool[J]. Journal of Place Management and Development, 2010, pp.57-
66.DOI:https://doi.org/10.1108/175383310110302 75

[3] Eshet,A. Sustainable Finance? The Environmental Impact of the Equator Principles and the CreditIndustry $[\mathrm{J}]$. International Journal of Innovation \& Sustainable Development,2017,pp.106-129.

[4] Zhu Guangyin, Wang Xiaoning, Li yanru. An empirical analysis of the internal motivation of commercial banks to implement green credit [J]. Monthly journal of Finance and accounting, 2017,pp.68-73. DOI:10.19641/j.cnki.421290/f.2017.18.011

[5] Liao Yun, Hu Weijuan, Yang Dandan. Dynamic analysis of the impact of green credit on bank operation efficiency -- Based on panel VAR model [J]. Journal of Finance and economics, 2019 ,pp. 57-64. DOI:10.13762/j.cnki.cjlc.2019.02.005 